\title{
Effect of grain shape to potential liquefaction
}

\author{
Arif Rahman ${ }^{1, *}$ \\ ${ }^{1}$ Magister Programm Department of Civil Engineering, Engineering Faculty, Andalas University Indonesia
}

\begin{abstract}
Earthqueke is one of the most frequent disaster in Indonesia, Earthqueke have caused losses both in terms of life and material. An earthquake also can trigger to soil liquefaction. Attention to liquefaction in Indonesia has raised after the Palu Earthquake in 2018. Liquefaction may happen in sandy soil in certain condition. Here, a series laboratory tests to study potentially liquefied in sandy soils is conducted. The liquefaction potential of sand are analyzed with the effect of the shape of the soil particles. The sandy sample is made up by special selected in three different shapes that are sharp, angular and round. Finally, it can be seen the effect of the shape of the soil grain on the liquefaction potential. The results of this study can be used to further investigation in order to mitigate the liquefaction.
\end{abstract}

\section{Introduction}

Earthquake disaster is one of the most frequent disasters in Indonesia that occurs in Indonesia which is located in prone to earthquakes which are traversed by the meeting of three tectonic plate paths, namely the Eurasian plate, the Australian Hindi plate, and the Pacific plate. The meeting point of this plate is in the sea so that large earthquakes with shallow depth can occur causing damage and loss both in terms of morale and material.

Earthquakes can also cause damage to the structure and loss of soil stability, soil damage caused by earthquakes, namely damage to the physical environment on the surface of the soil and damage to the buildings above it. Damage to the physical environment on the surface in the soil, for example slope balance (landslides and slope stability problems), land subsidence (sattlement), and liquefaction (liquefactions). In this case the author is interested in discussing the phenomenon of liquefaction.

Liquefaction is a phenomenon of loss of soil shear strength in the saturated layer of water caused by an earthquake, so that the soil experiences collapse and behaves like a liquid (liquid). Liquidation usually occurs in granular (non-cohesive) soil saturated with water and receives cyclic loads in the form of earthquakes (Kremer, 1996)[1].

Effect of liquefaction of building and infrastructure destroyed for example by liquefaction destroying Sheffield dam after the Santa Barbara earthquake in California in 1925, failure of carrying capacity in Kawagishi-cho apartment buildings after the Japanese Niiagata earthquake in 1964 was caused by liquefaction and liquefaction phenomena in Indonesia itself. which caused a lot of losses and casualties in the area of Palu, Central Sulawesi in 2018.
Based on the phenomena that happen, it is very necessary to anticipate the steps so that this does not happen again, for that disaster mitigation is carried out in earthquake-prone areas. There have been many tests conducted to analyze the potential for liquefaction to occur both in the field and in the laboratory.

Determine liquefaction using grain size gradient curve analysis using a sieve test with a decreasing curve that occurs (Siahaan: 2015)[2]. determine the potential of liquefaction using the sondir test data, using the Seed and Idriss calculation method (Lastaruna: 2009)[3]. determine the potential for liquefaction multiplied by opaque using the shaking table (Mase: 2013)[4]. Laboratory liquefaction test of sand based on grain size and relative dansity (Hakam: 2016)[5].

In this study the authors are interested in testing the effect of grain shape to potentonal liquefaction by means of the shape of the soil granules made / selected in such a way that the variations are three parts in sharp, angular and round shape. Sand is placed in a saturated condition in a vessel on a flat table and then given a vibration with certain variations. During the testing the amplitude is recorded, besides monitoring changes that occur in soil samples that have the potential to cause liquefaction.

\section{Literature review}

Indonesia is on the most active earthquake path in the world because it is surrounded by the Pacific Ring of Fire. Earthquake is a vibrational event of the earth due to the sudden release of energy in the earth which is characterized by the breaking of rock layers in the earth's crust. Energy accumulation that causes earthquakes results from the movement of tectonic plates. The energy produced is emitted in all directions in the form of earthquake waves so that the effect can be felt to the

\footnotetext{
$\bar{*}$ Corresponding author: rahman.arif2306@gmail.com
} 
surface of the earth (Meteorology, Climatology and Geophysics).

Most of the earthquakes originated from tectonic activities, which cover $90 \%$ of all earthquake activities. These earthquakes are directly related to the activities of tectonic plates which continue to be related to the process of forming mountains, faults and pulls or stresses from the movement of the plates making up the earth's crust. The number of earthquakes that occur due to the geography of Indonesia is in a meeting of a number of large active tectonic plates where each plate movement has the potential to cause earthquakes. The current geological region of Indonesia occurs as a result of the interaction of 3 major plates of the world, namely the Eurasian plate, the Australian Hindi plate, and the Pacific plate.

Liquefaction is the process of changing a saturated sandy soil into a liquid, due to porous air pressure (pore water pressure) caused by an earthquake load (cyclic), so that the effective stress of the ground becomes zero. Related, the strength of the land at this time is decreasing, causing failure in supporting the building above (Lestari et al, 2014)[6].

Vibration in the soil which most often triggers an increase in pore water pressure is the vibration originating from an earthquake, but activities related to construction such as blasting can also cause an increase in the pore water pressure. Liquidation usually occurs in water-saturated soil, where all the cavities of the soil are filled with water. When experiencing vibration, this water provides the density of the soil. Soils that experience liquefaction are also higher in pressure on the retaining wall which can cause the structure to tilt or slide. This movement can cause land degradation (settlement) and structural damage to the ground.

Sampling was carried out from 6 different location points, where the location was a place with important functions and activities including the Mesjid Terapung of Pariaman City, Shipping Polytechnic in Pariaman Regency, Rusunawa Lubuk Buaya, Pantai Gajah Air Tawar Barat (behind Padang State University), Port of Teluk Bayur, and Pertamina Bungus.

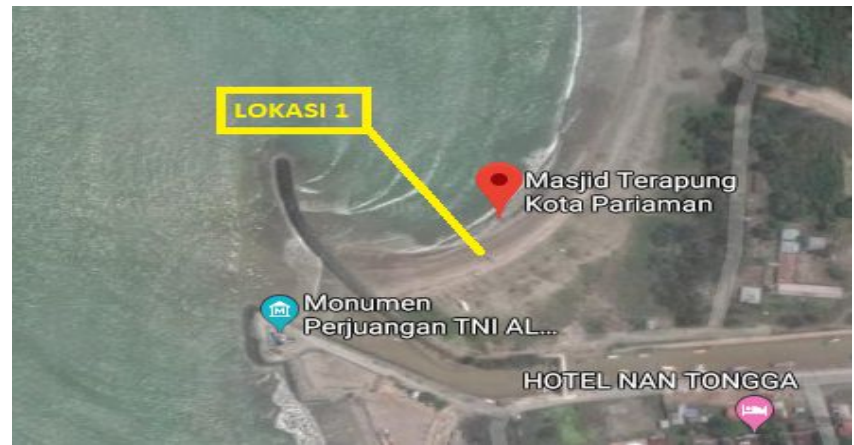

Fig 1. Mesjid Terapung of Pariaman City

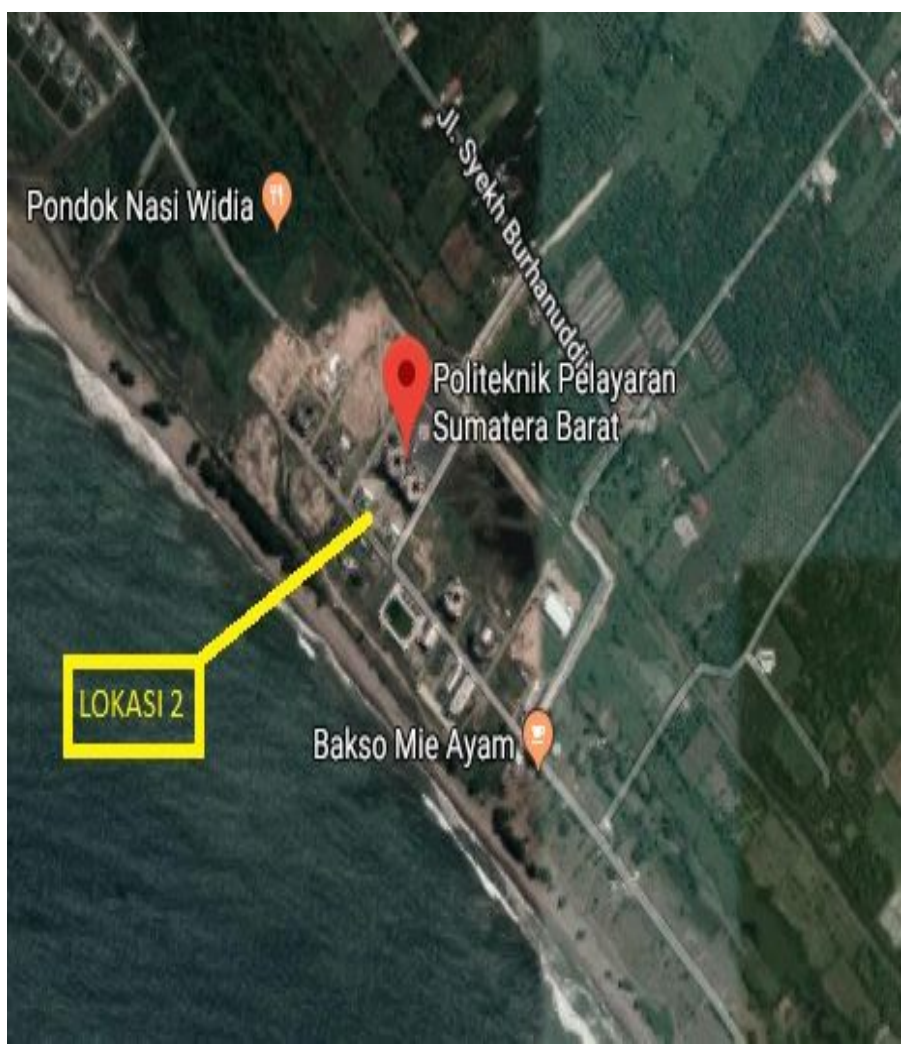

Fig 2. Shipping Polytechnic in Pariaman Regency

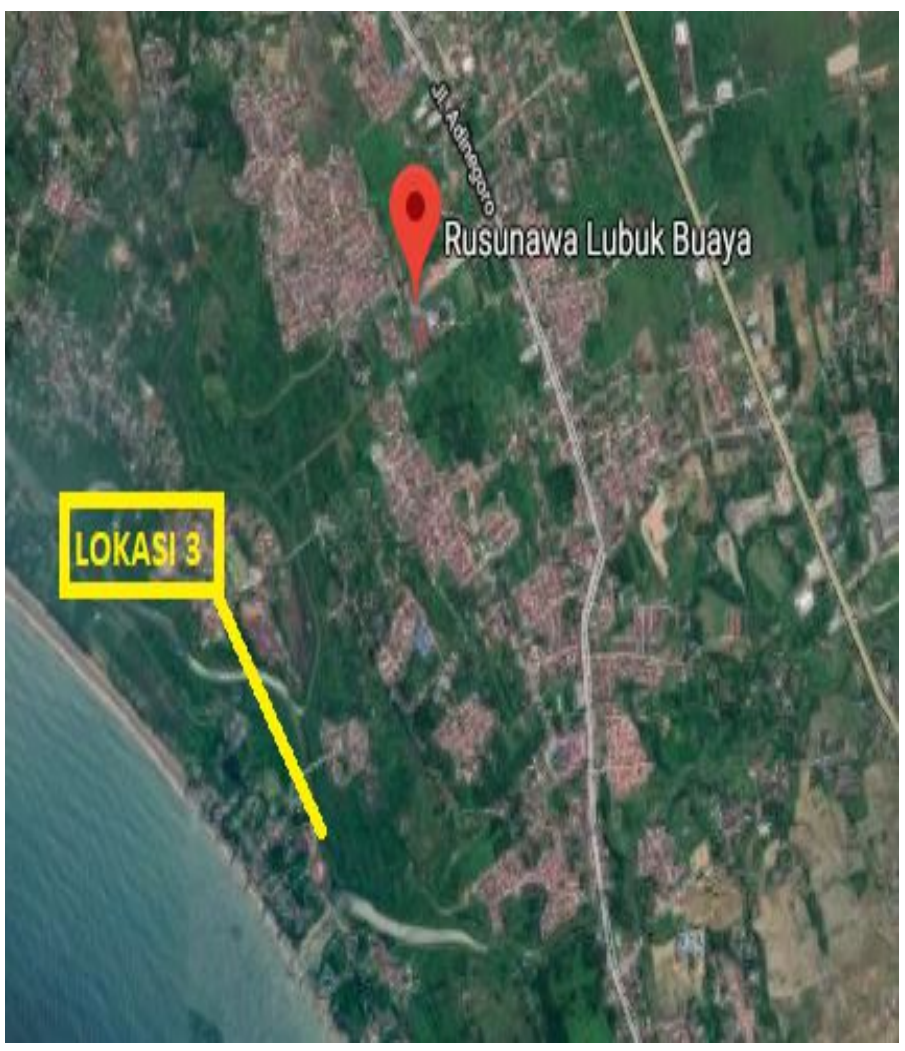

Fig 3. Rusunawa Lubuk Buaya 


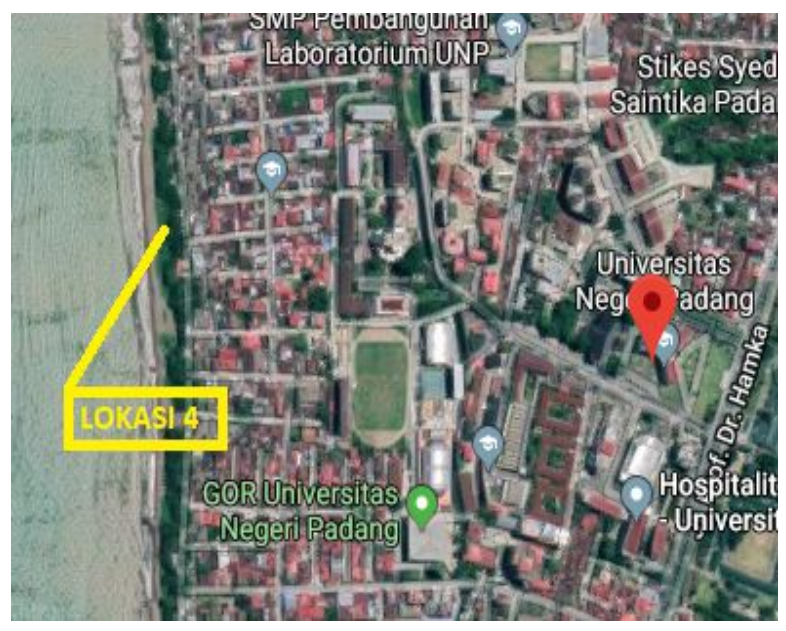

Fig 4. Pantai Gajah Air Tawar Barat (behind Padang State University)

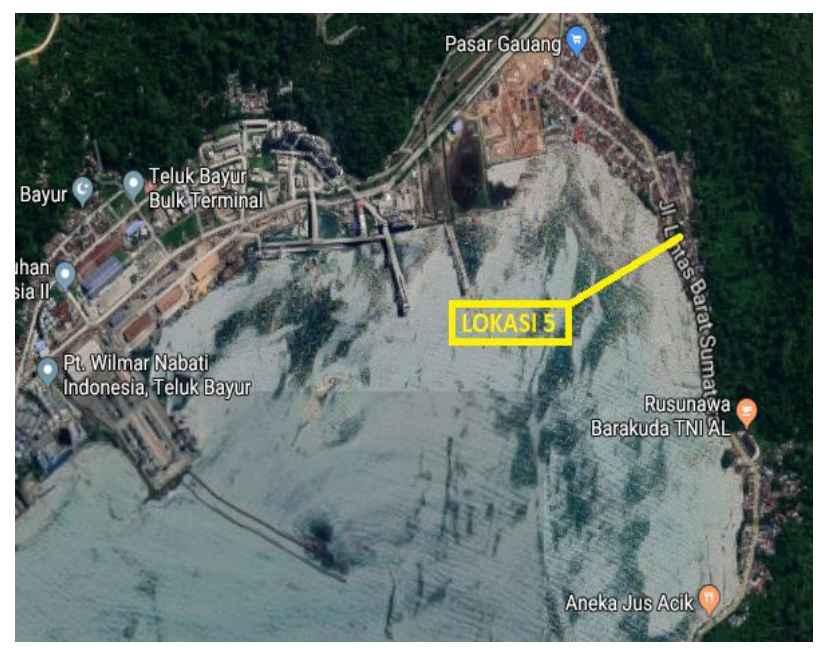

Fig 5. Port of Teluk Bayur

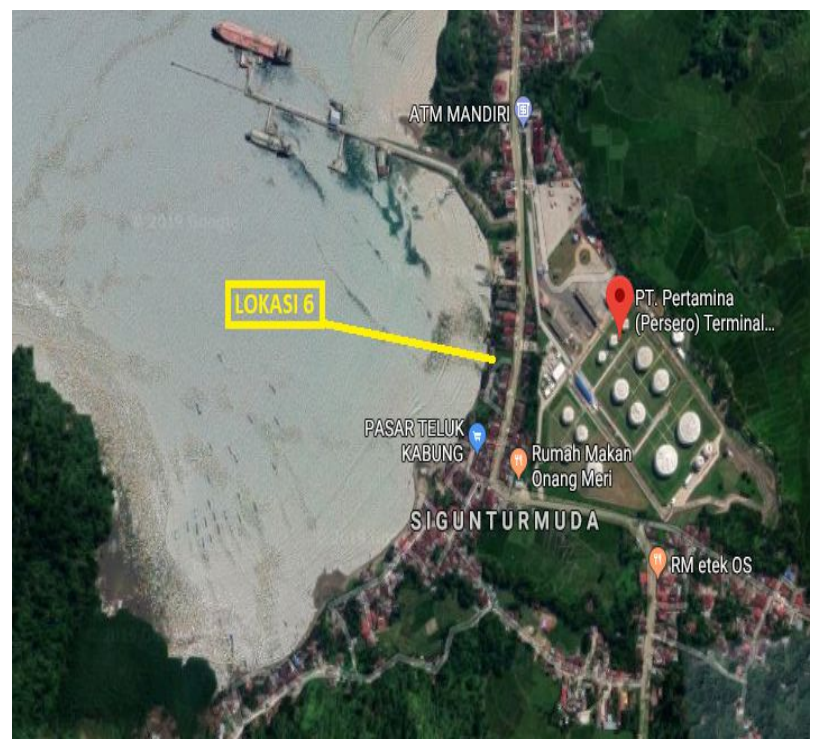

Fig 6. P.T Pertamina Bungus

\section{Methodology}

The procedures of this study are following:

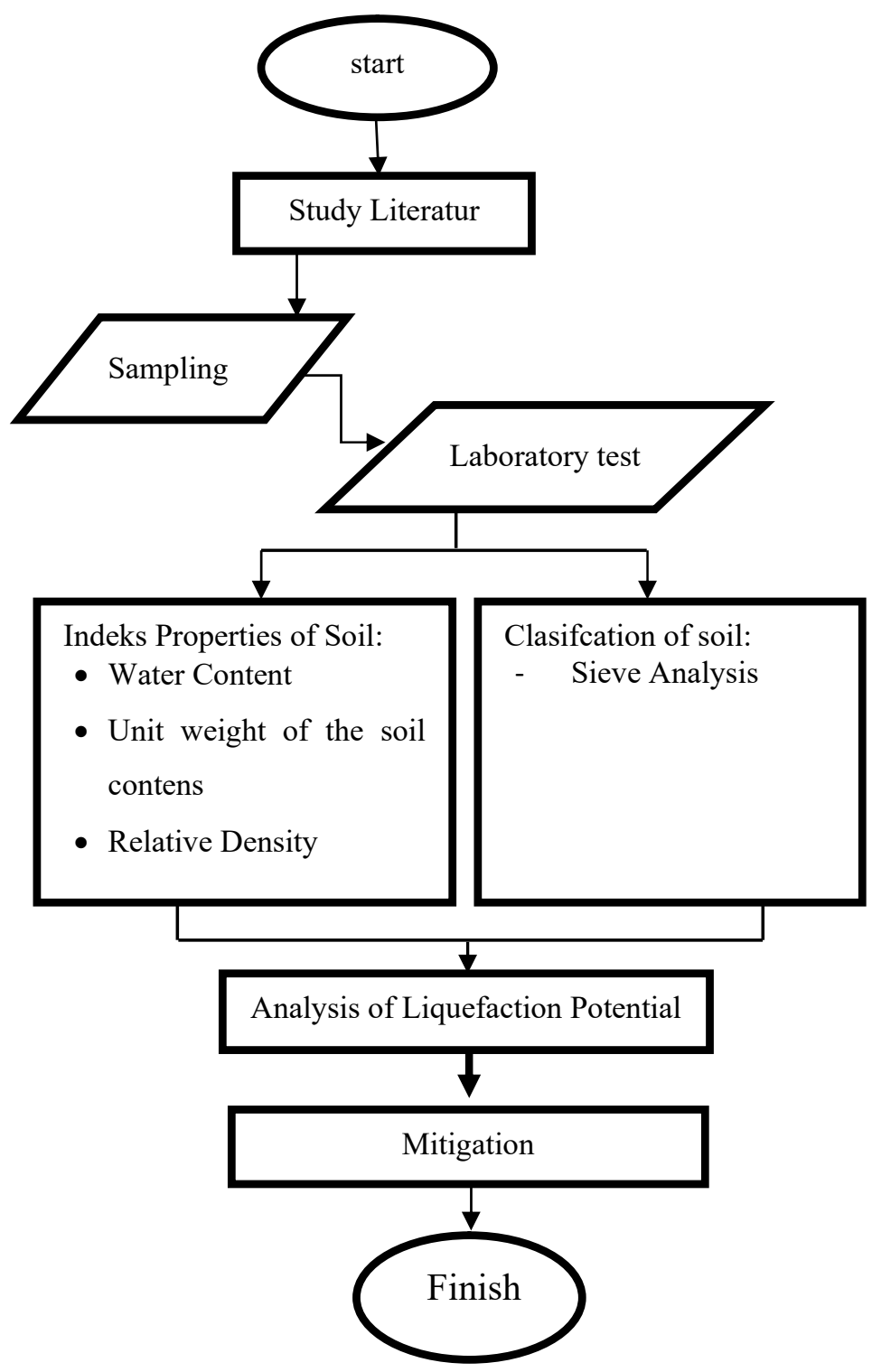

\section{Result and Discusions}

\subsection{Index Properties of Soil}

Best on the test results in the laboratory obtained index properties of soil values as follows:

Tabel 1. Index Properties of Soil

\begin{tabular}{ccccc} 
Sample & $\gamma(\mathrm{gr} / \mathrm{cm} 3)$ & $\mathrm{W}$ & $\gamma \mathrm{d}$ & $\mathrm{Dr}$ \\
\hline 1 & 1,778 & 8,820 & 1,634 & 3,712 \\
\hline 2 & 1,611 & 5,450 & 1,528 & 2,196 \\
\hline 3 & 1,473 & 8,870 & 1,353 & 1,819 \\
\hline 4 & 1,644 & 9,410 & 1,503 & 1,668 \\
\hline 5 & 1,490 & 7,870 & 1,381 & 1,697 \\
\hline 6 & 1,622 & 5,480 & 1,538 & 1,303
\end{tabular}

From the data index properties of soil, it can be concluded that the test soil is very loose with very low granular bearing capacity and if an earthquake occurs it 
will result in an increase in the ground water level resulting in liquefaction. After finding the index value of the property of soil then proceed to look for the value of the pore number (e) using the equation:

$$
\mathrm{e}=(\text { Gs. } \gamma \mathrm{w} / \gamma \mathrm{d})-1
$$

Tabel 2.. Void Ratio

\begin{tabular}{rcrrrr} 
Sample & \multirow{2}{*}{ Gs } & $\gamma \mathrm{w}$ & $\gamma \mathrm{d}$ & $\mathrm{a}$ & $\mathrm{e}$ \\
\cline { 5 - 6 } & & & & $(\mathrm{Gs} . \gamma \mathrm{w})$ & \\
\hline 1 & 2,658 & 1 & 1,634 & 2,658 & 0,627 \\
\hline 3 & 2,660 & 1 & 1,528 & 2,66 & 0,741 \\
\hline 4 & 2,659 & 1 & 1,353 & 2,659 & 0,965 \\
\hline 5 & 2,655 & 1 & 1,503 & 2,655 & 0,766 \\
\hline 6 & 2,654 & 1 & 1,381 & 2,654 & 0,922 \\
\hline
\end{tabular}

The large pore value value will result in reduced soil density, as a result of the reduced soil density, the potential for liquefaction is greater than the condition of fewer pore numbers which have less density.

then proceed to look for uniformity values $(\mathrm{Cu})$ and gradation of grain $(\mathrm{Cc})$ with the following results:

Tabel 3. Values for $\mathrm{Cc}$ and $\mathrm{Cu}$

\begin{tabular}{ccc} 
Sample & $\mathrm{Cu}$ & $\mathrm{Cc}$ \\
\hline 1 & 2,29 & 1,18 \\
\hline 2 & 1,56 & 0,90 \\
\hline 3 & 1,91 & 1,25 \\
\hline 4 & 1,72 & 1,41 \\
\hline 5 & 2,55 & 0,88 \\
\hline 6 & 1,38 & 0,96
\end{tabular}

Based on the six samples examined, soil that has a high level of uniformity is the sample in the mesjid terapung of Pariaman city.

\subsection{Liquefaction potential}

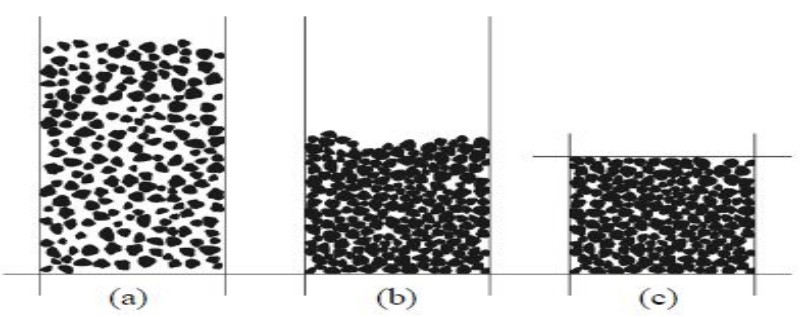

Fig 7. (a) rounded shape. (b) angular (c) sharps
Based on Figure 2 taken from research (Ashmawy at all : 2003)[7], image (a) has a larger cavity than images (b) and (c). If the cavity between the grains is larger, then the bonding capacity between the grains is reduced. So that the soil density is reduced and the soil is vulnerable to liquefaction.

\section{Conclusion}

From the data index properties of soil, it can be concluded that the test soil is very loose with very low granular bearing capacity and if an earthquake occurs it will result in an increase in the ground water level resulting in liquefaction.

Based on the six samples examined, the land that has a high level of uniformity is the sample in sample 1 in the Mesjid Terapung in Pariaman city. Soil with high uniformity and poor grain grading and has a large intergrain cavity so that the inter-grain binding capacity is reduced, then water fills the cavity between soil grains which results in soil compaction, this has the potential to experience liquefaction

\section{References}

1. A. Mecke, I. Lee, J.R. Baker jr., M.M. Banaszak Kramer, S.,L., Geo. Earthq. Engg. Prantice hall. New Jersey.NJ07458. ISBN 0-13-374943-6. (1996)

2. Siahaan, S., P., Experiment of Potential Liquidation in Uniform Sand Land with Modeling Tools in Laboratories. Undergraduate thesis, Andalas University. (2015)

3. Lastaruna D., Liquefaction Potential Analysis Based on Sondir Testing Data (Case Study of Haji Agus Salim and Lapai GOR, Padang) Undergraduate thesis, Andalas University. (2009)

4. Mase, L.,Z., J. Civil Engg. (2013).

5. Hakam. A., Laboratory liquefaction test of sand based on grain size and relative dansity. Civil Engineering Department. Engineering Faculty of Andalas University. (2016).

6. Lestari A,. Liquifaction Potential Study Based on the Critical State Concept and Piezocone Test in Padang City's Sediment Sediments. Research Institutions and Community Service. Parahyangan Catholic University (2014).

7. Ashmawy., Evaluating the Influence of Particle Shape on Liquefaction Behavior Using Discrete Element Modeling. Department of Civil and Environmental Engineering. University of South Florida Tampa, Florida, USA(2003) 